\title{
CHANGES IN THE STRUCTURE IN EU COUNTRIES
}

\author{
Manuela Raisova ${ }^{1}$
}

Received: December 1, 2018 / Revised: January 30, 2019/ Accepted: March 20, 2019

(C) Association of Economists and Managers of the Balkans, 2019

\begin{abstract}
The divergent developments in productivity and employment over the past two decades, as well as the crisis and subsequent recovery of the global economy have led to significant changes in different parts of the economic structure in all EU countries. The aim of our study was to examine changes in the basic segments of the economic structure of European countries. The development of segments is assessed through the indicator of gross added value (in current prices) and employment in the period 1995 to 2017. We compared the situation of the two main groups of European countries - the original and new EU countries. We note that there are significant differences between these groups, especially in the 1990s. Subsequently, there have been changes in the structure of new countries that have narrowed the gap between countries. The structural gap between countries has slowly diminished in average. However, the crisis has significantly delayed the process of convergence and the economic recovery period has not recovered to the pre-crisis situation. On the contrary, after the end of crisis the structural gap has thus re-expanded in a number of cases. In this article we target on the comparison of Estonia and Germany. Estonia represents precisely the group of countries whose structural gap has widened after the end of the crisis. On the other hand, the German economy is seen as a stable backbone of European politics and economics. We considered Germany the most economically strong representative of the old EU countries. From this point of view, our research was based on the assumption that Estonia wants to bring its economy closer to Germany's economy. We monitored whether the Estonian economy was getting closer or moved away from the German economy. Our results confirmed that Germany's economy is stable and more or less unchanged for more than 20 years. However, the assumption that Estonia's economy is moving closer to Germany's economy has not been confirmed. The opposite is probably true.
\end{abstract}

Keywords: Structural Gap, Structural deviation, Estonia, Germany, Gross Value Added, Employment

\section{JEL Classification L16}

This paper was presented at the Second International Scientific Conference on IT, Tourism, Economics, Management and Agriculture - ITEMA 2018 - November 8, 2018, Graz, Austria, www.itema-conference.com

Manuela Raisova

manuela.raisova@tuke.sk

1 Technical University of Kosice, Faculty of Economics, Nemcovej 32, 04001 Kosice, Slovakia 


\section{INTRODUCTION}

Estonia, as well as other European countries, changed very significantly under the influence of both external and internal political and socio-economic factors. In particular, the relatively challenging process of transforming the economy into a market economy and its subsequent establishment on European markets has prompted many changes.

The aim of the article is to highlight the main changes in the structure of the Estonian economy. We assumed that Estonia, as a part of its transformation, tried to adapt to modern trends in Europe as much as possible. In the last two decades there is an increase of service share in gross value added in the European states (we are talking about the original EU states). This is also related to the involvement of countries in global value chains and the overall development of global production. Thus, we have tried to examine whether Estonia has also reorientated from the traditional sectors - agriculture and industry - to service industries.

We assumed that the effort of Estonia to enter the EU and later the EMU was a strong motivation of economic structure transformation according to the model of developed European countries. Implemented changes should accelerate the convergence of the country to an advanced Europe and its markets. Germany represents advanced Europe in our analysis. Thus, we assumed that the structural gap between Estonian economy and German economy is not more than 5\%.

\section{METHODS AND PROCEDURES}

We used the industry classification NACE (Rev. 2) to investigate changes in structure, with the economy divided into 10 sectors. The changes were monitored in the period 1995-2017. However, 22 years is a very long series of data. For the purposes of this article, however, we chose only two years to compare - 1995, the beginning of the period and 2017 as the end of the period. Primary variables were gross added value (in current prices) and employment (in thousands of people). All used values were available in the Eurostat and OECD databases. Missing data was complemented by country statistical data.

When examining the structural gap, we relied on the Dujava (2010) methodology and the structural gap was calculated as follows:

$$
\begin{aligned}
& s=100 * \sqrt{\sum_{i=1}^{11} h_{i} *\left(\frac{G V A_{i ; E S T}}{G V A_{E S T}}-\frac{G V A_{i ; G E R}}{G V A_{G E R}}\right)^{2}} \\
& h_{i}=\frac{1}{2}\left(\frac{G V A_{i, E S T}}{G V A_{E S T}}+\frac{G V A_{i ; G E R}}{G V A_{G E R}}\right)
\end{aligned}
$$

where:

s - Structural deviation indicator;

$\mathrm{h}_{\mathrm{i}}$ - i - th sector;

VA $_{i \text { c country }}$ - the GVA of "i-th" sector in Estonian economy;

$\mathrm{VA}_{\text {country }}$ - the total GVA in Estonian economy;

$\mathrm{VA}_{\mathrm{i} \text {, EU15 }}$ - the GVA of "i-th" sector in German economy;

$\mathrm{VA}_{\mathrm{EU} 15}$ - the total GVA in German economy 
The volume of the structural wobble index is increasing with the growing differences between the share of individual sectors in the economy of the Estonia and German economy. (Dujava, 2010) For the calculation of the structural deviation in employment, the employment replaced GVA.

Throughout the article, we will use the following abbreviations for each segment (Table 1):

Table 1: Segment names and their abbreviations; Source: (Eurostat, 2008)

\begin{tabular}{|l|c|l|c|}
\hline \multicolumn{1}{|c|}{ Segment } & Abbr. & \multicolumn{1}{|c|}{ Segment } & Abbr. \\
\hline Agriculture, forestry and fishing & AFF & Financial and insurance activities & FIA \\
\hline Industry (except construction) & IND & Real estate activities & REA \\
\hline Construction & WRT & $\begin{array}{l}\text { Professional, scientific and technical } \\
\text { activities; administrative and support } \\
\text { service activities }\end{array}$ & $\begin{array}{l}\text { Public administration, defence, } \\
\text { education, human health and social } \\
\text { work activities }\end{array}$ \\
\hline $\begin{array}{l}\text { Wholesale and retail trade, transport, } \\
\text { accomodation and food service } \\
\text { activities }\end{array}$ & ICO & $\begin{array}{l}\text { Arts, entertainment and recreation; } \\
\text { other service activities; activities } \\
\text { of household and extra-territorial } \\
\text { organizations and bodies }\end{array}$ & PDE \\
\hline Information and communication & AER \\
\hline
\end{tabular}

\section{CHANGES IN THE ECONOMIC STRUCTURE}

\section{Germany}

Analysis of German economy structure has shown that there has been no fundamental change in its structure over 22 years. Industry was one of the strongest sector. It generated more than $26 \%$ of the total gross value added of the economy. (Figure 1) Nevertheless, the OECD (1995) assessed that its innovative capacity seems to have been impaired by excessive regulation and bureaucratic inertia, making for slow growth in services and some hi-tech sectors. In the field of employment, the OECD also criticized the fact that although unemployment was relatively low, labor incentives were adversely affected by high taxes, generous benefits, job-protection provisions, and restricted wage and working time flexibility. (OECDa, 1995)
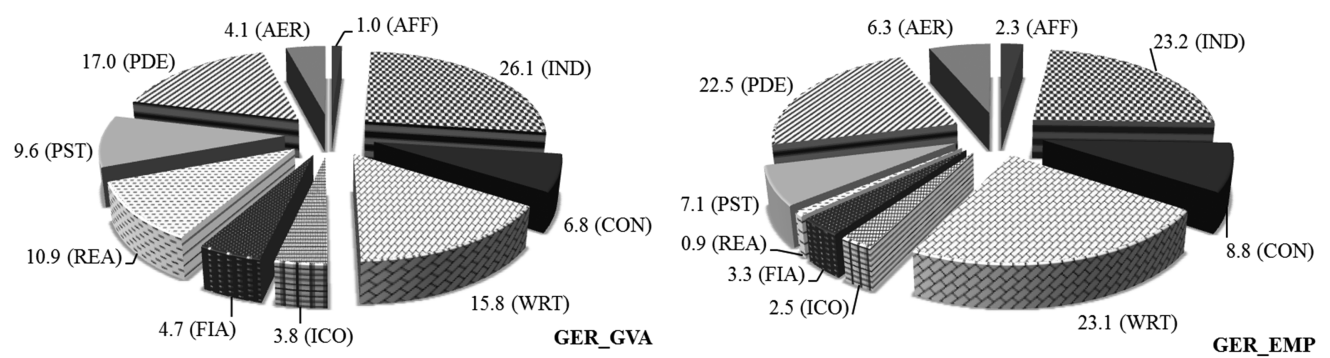

Figure 1 Structure of the German economy according to GVA and EMP in 1995 (\%) Source: own calculation based on (Eurostat1,2, 2018)

Germany has responded to these remorse by extensive reforms, which it has gradually implemented into its structure. The most powerful impetus for further development was the privatization of 
large service companies such as Deutsche Telekom, Lufthansa and others. Reforms also covered other key areas such as the financial sector, private ownership of businesses, the labor market and the tax system. (OECDa, 1995)

Based on the data, we note that there have been no significant changes in the structure of gross value added over 22 years (Figure 2). However, reforms and innovations have led to a rise in gross value added of 1.6 times. (OECDb, 2018) According to the latest Forum's Global Competitiveness Report, Germany is the world's most innovative economy. Germany has invested mainly in the automotive industry, software engineering and e-mobility projects. (Whiting, 2018) The result is not only the first place among innovators but also significant changes in the structure of employment and productivity. The share of services in the economy has grown considerably and the share of industry has declined. The growth of employment in services (by 32\%) was also driven by the growth of value added (by 70\%), but the value added per one employee increased only 1.3 times. On the other hand, even because of innovation, fewer employees work in the industry (a drop of $7 \%$ ), but the added value of the segment increased (by 70\%) and the value added per employee increased 1.7 times. This is one of the reasons why industry in Germany belongs to very strong segments of the economy. However, it is true that the creation of gross value added is a long-term aspect of the service segment.
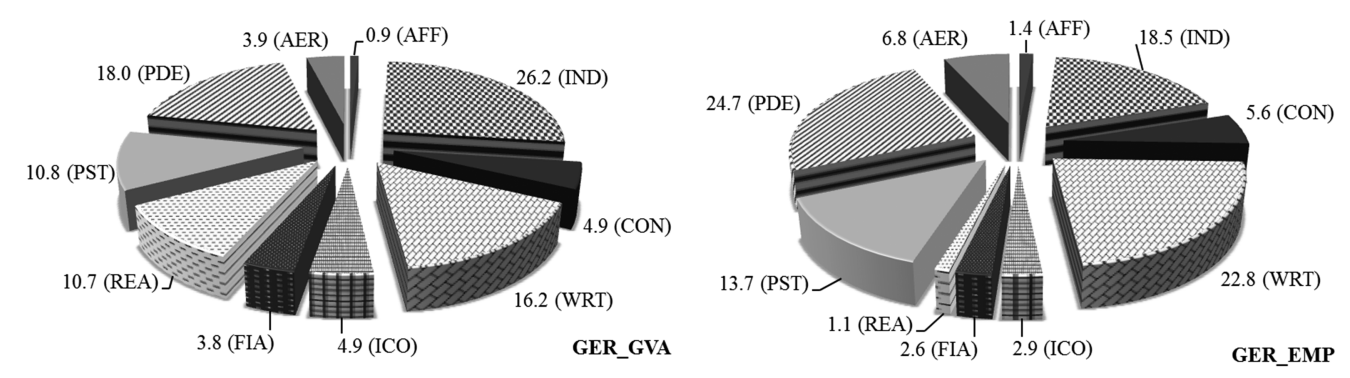

Figure 2 Structure of the German economy according to GVA and EMP in 2017 (\%) Source: own calculation based on (Eurostat1,2, 2018)

\section{Estonia}

As early as the beginning of the period, the structure of the Estonian economy differed significantly from Germany's economy, particularly in two respects:

- the agriculture segment represented not only a nearly $6 \%$ share of the gross added value of the economy ( $1 \%$ in Germany), but also a more than $10 \%$ share of employment in the economy $(2.3 \%$ in Germany).

- the WRT segment was much more involved in gross value added than in Germany. At the same time, it had a greater share in employment, even though the difference was not so significant. (Figure 3)

The period of restructuring and the transformation of the economy has led to a significant increase in the share of the REA segment. The growth of the WRT sector was mainly driven by the government program for the restructuring of transport and trade. The government has also sought to adapt to the trend of computerization, and the public school-funded Estonian school computerisation program Tiger Leap was a positive impulse in this area. (Europa, 1998) The result was an increase in ICO's share not only in value added, but also in employment. 

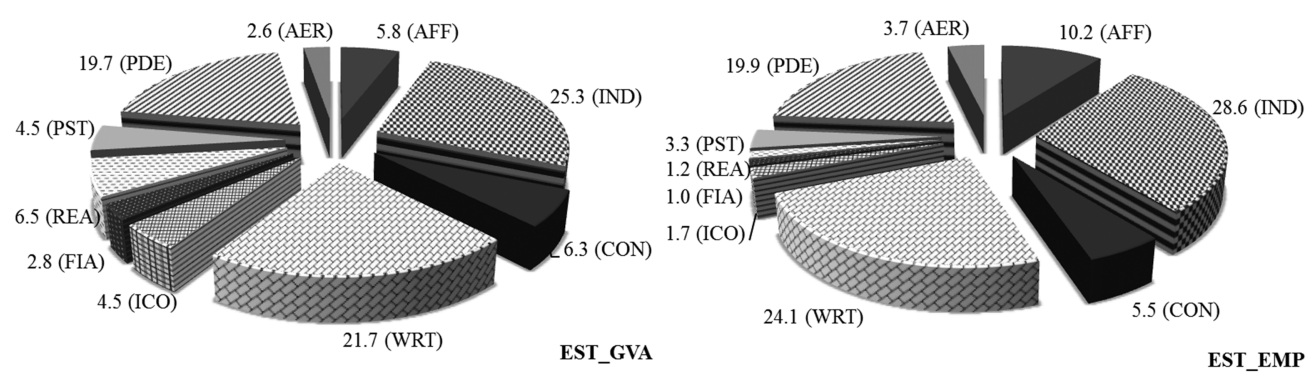

Figure 3 Structure of the Estonian economy according to GVA and EMP in 1995 (\%); Source: own calculation based on (Eurostat1,2, 2018)
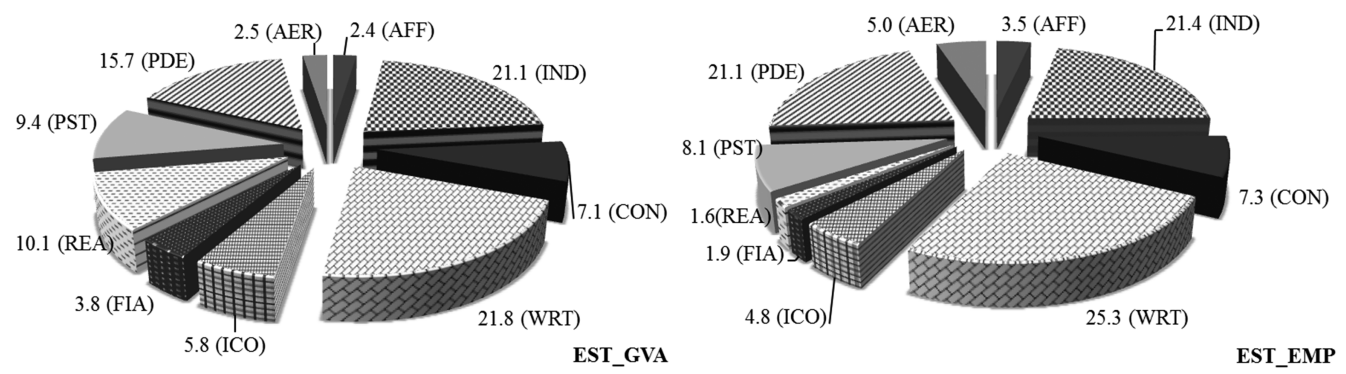

Figure 4 Structure of the Estonian economy according to GVA and EMP in 2017 (\%) Source: own calculation based on (Eurostat1,2, 2018)

Estonia is one of the countries in which it was possible to see a major transformation from the agro-industrial focus to focus on services. Already during the first five years the share of agriculture in the gross added value has decreased by almost $1.5 \%$. Over the next few years, the share of agriculture has declined in both production and employment. The most striking expression of the retreat from traditional sectors is seen in the field of employment. (Figure 3 and 4) Only one-third of 1995 employees continue to work in this segment in 2017. We also see a decline in employment in the IND segment. From this segment, up to $24 \%$ of employees went up compared to 1995 . About the same increase in the share of employment is in the services segment. At the same time, we note that the Estonian economy has grown productively in all its segments. The transformation process, and in particular the innovative programs, have ranked Estonia among the 35 most innovative countries in the world (the Forum's Global Competitiveness Report ranked 32nd). (Schwab, 2018)

\section{STRUCTURAL GAP BETWEEN ESTONIA AND GERMANY}

The aim of any economically weaker country is to get closer to the economically stronger countries. Countries that have joined the EU since 2004 are or were considered to be economically weaker countries than the old European countries. Our aim was to find out whether Estonia were structurally approaching Germany in the period 1995-2017 or not. We have calculated the structural gap measured by structural deviation between Estonia and Germany.

Based on our calculations, the Estonian economy is not structurally approaching the economy of Germany either by gross added value or by employment. (Figure 5) The structural deviation by gross value added ranged from $3.5 \%$ (in 1995) to 6.1\% (in 2007). The average deviation value is 
$4.98 \%$. The crisis period was the only moment in which it seemed that the structural deviation was smaller. However, as it is a period in which both countries have slowed down their productivity, it is only a distortion.

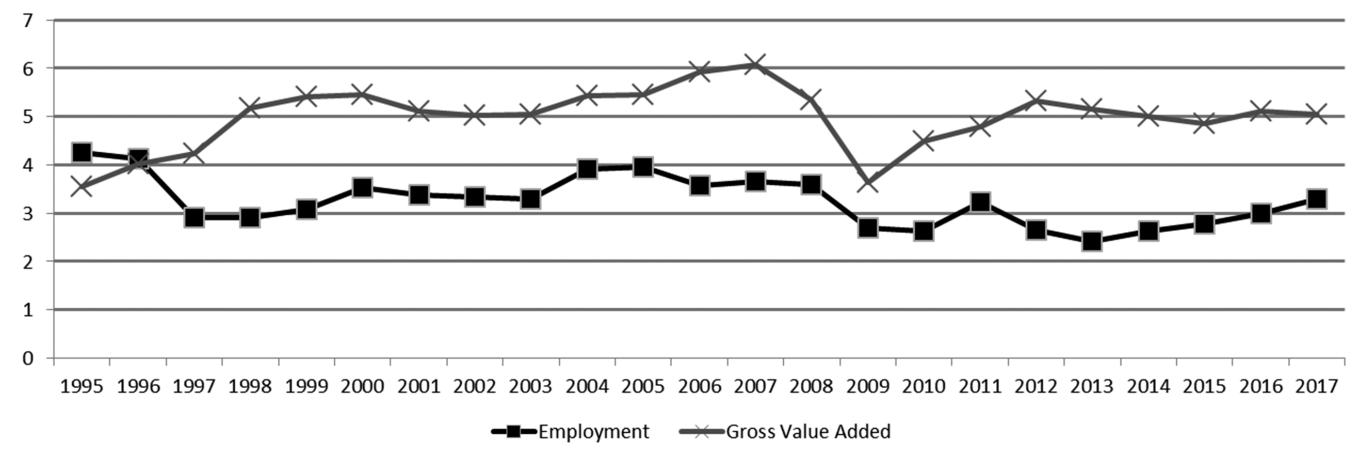

Figure 5 The structural deviations_Estonia and Germany (\%)

Source: own calculation

The slump in the economy is also supported by the development of the structural deviation by employment. Its value ranged from $2.42 \%$ (in 2013) to $4.25 \%$ (in 1995) and the average variance was $3.25 \%$. Since the end of the second wave of the economic crisis (since 2013), this deviation has been increasing. The results reflect the situation the OECD criticizes in relation to Estonia. According to the OECD, the country lacks an effective dual system of education that would allow effective interconnection of secondary education with practice. Shortages of skilled labor contributes to structural unemployment and constrain competitiveness while out-of-work working-age individuals face a higher poverty risk. OECD therefore recommends improving access to upper-secondary vocational education by providing more financial assistance to students. Expand workplace-based training by introducing a tax-free lower minimum wage for apprenticeships. Strengthen collaboration of business and schools at the local level. (OECDc, 2017)

\section{CONCLUSIONS}

Since 1995, Estonia has undergone several milestones that have changed its internal structure. These changes are particularly significant in terms of changing the position of the original segments - agriculture and industry. In an effort to establish itself in the European area, Estonia has adapted itself to the trend of European countries and the position of the service segment has grown considerably in both gross value added and employment over the last 22 years. Nevertheless, industry and, above all, agriculture continue to play a very important role in the economy of Estonia. Based on the results, we state that our assumption about the adaptation of Estonia to the countries of advanced Europe has been fulfilled.

Germany is in a completely different position. The structure of the economy has essentially not changed in the last 22 years. However, the implementation of innovation has enabled more efficient production, leading to long-term growth in the economy. We see a more significant change only in the case of the employment structure in individual segments where, as in Estonia, there is a clear shift of staff to the service segment. In this respect, we can talk about similarities in development in both countries. 
From the point of view of Estonia's structural convergence towards Germany, we note that Estonia has not been successful in this area yet. As the results show, the average value of the structural gap by value added is $4.98 \%$ and the structural gap by employment is $3.25 \%$. In both cases, our assumption of less than $5 \%$ was confirmed. However, the evolution of the economy over the past 5 years has shown that this gap is rather widening than diminishing. If the implementation of the new reforms does not produce the desired effect, then there is a high probability that the structural gap will exceed the $5 \%$ threshold.

\section{ACKNOWLEDGMENT}

This paper was written in connection with scientific project VEGA no. no. 1/0961/16. Financial support from this Ministry of Education`s scheme is also gratefully acknowledged.

\section{REFERENCES}

Dujava, D. (2010). Komparácia štruktúry ekonomiky SR a EÚ 15. EÚ SAV Working Papers. Retrieved from: http://www.ekonom.sav.sk/sk/publikacie/wp-24-komparacia-strukturyekonomiky-sr-a-eu-15-p136.

Europa. (1998). Regular Report From The Commission On Estonia's Progress Towards Accession. Retrieved from: https://ec.europa.eu/neighbourhood-enlargement/sites/near/files/archives/pdf/key_documents/1998/estonia_en.pdf

Eurostat. (2008). NACE rev. 2. Statistical classification of economic activities in the European Community. Retrieved from: https://ec.europa.eu/eurostat/documents/3859598/5902521/ KS-RA-07-015-EN.PDF.

Eurostat1. (2018). Gross Value Added. Retrieved from: https://ec.europa.eu/eurostat/web/products-datasets/-/med_ec5.

Eurostat2. (2018). Employment. Retrieved from: https://ec.europa.eu/eurostat/web/products-datasets/-/nama_10_a10_e.

OECDa. (1995). OECD Economic Survey: Germany 1995. OECD. Retrieved from: https://www. oecd-ilibrary.org/economics/oecd-economic-surveys-germany-1995_eco_surveys-deu1995-en

OECDb. (2018). OECD Economic Survey: Germany 2017. OECD. Retrieved from: http://www. oecd.org/eco/surveys/economic-survey-germany.htm

OECDc. (2017). Estonia: Structural Reform Priorities. OECD. Retrieved from: http://www.oecd. org/eco/growth/Going-for-Growth-Estonia-2017.pdf

Schwab, K. (2018). The Global Competitiveness Report 2018. World Economic Forum. Retrieved from: https://www.weforum.org/reports/the-global-competitveness-report-2018

Whiting, K., (2018). Germany is the world's most innovative economy. World Economic Forum. Retrieved from: https://www.weforum.org/agenda/2018/10/germany-is-the-worlds-most-innovative-economy 